\title{
INTESTINE MORPHOMETRICS OF FISHES: A COMPILATION AND ANALYSIS OF BIBLIOGRAPHIC DATA
}

\author{
Paraskevi K. KARACHLE* and Konstantinos I. STERGIOU
}

Laboratory of Ichthyology, Department of Zoology, School of Biology, Aristotle University, Thessaloniki, Greece

Karachle P.K., Stergiou K.I. 2010. Intestine morphometrics of fishes: a compilation and analysis of bibliographic data. Acta Ichthyol. Piscat. 40 (1): 45-54.

\begin{abstract}
Background. The examination of morphological features related to feeding in fish, as well as their relation with body length, are of increasing scientific interest. In the present study, information on intestine (gut) morphometrics that appear in the relevant literature has been compiled, analysed, and discussed.

Materials and Methods. Search of gut-related bibliography was conducted, using online literature databases on fish feeding and ecomorphology. The resulted data was tabulated. Relationships between mean, minimum, and maximum relative gut length (RGL) and intestine length weight index (ILW, Zihler's index), as provided by the original author, with species' fractional trophic levels (TROPHs; extracted from FishBase) were explored. Finally, using the relations between gut length $(\mathrm{GL})$ and body length $(L)$ provided by the original authors, regressions were reconstructed and compared based on species' feeding habits and taxonomy.

Results. The amount of information related to gut morphometrics referred to 498 species. The relations between GL and $L$ referred to 71 species, but four species were omitted from the analyses. Mean, minimum, and maximum RLG and ILW values were negatively related (for all cases: $P<0.01$ ) with TROPH. The GL $-L$ regressions performed for 67 species revealed the presence of two major groups as herbivorous fishes and carnivorous fishes. Grouping according to species' taxonomic order did not form any significant groupings.

Conclusion. Existing information on intestine morphometrics is generally accumulated in a few scientific papers. All the analyses performed on the compiled data reinforced the pattern generally accepted that herbivores have longer intestines than carnivores. In addition, the influence of species' evolutionary history on comparisons of gut length between species with different feeding habits was not verified. Finally, equations relating RGL and ILW to TROPH can be used for TROPH value estimates from morphological data that are easy to obtain, especially in the lack of species' feeding habits data.
\end{abstract}

Keywords: fish gut, relative gut, intestinal indices, bibliographic references

\section{INTRODUCTION}

In fishes, both external (e.g., shape, size and position of mouth, shape of caudal fin) and internal morphology (e.g., stomach shape and size, gut length: GL) provide important information on a species' feeding ecology (e.g., Keast and Webb 1966, Schmitt and Holbrook 1984, Kaiser and Hughes 1993, Juanes 1994, Juanes and Conover 1994, Hart 1997, Wootton 1998). Exploration of the relations between various feeding-related morphological characteristics with body length ${ }^{* *}$, such as body girth (e.g., Stergiou and Karpouzi 2003), mouth dimensions (horizontal and vertical mouth opening, gape area; e.g., Karpouzi and Stergiou 2003), and GL (e.g., Karachle and Stergiou 2006, 2007), are of great importance for understanding the biology and ecology of fishes (e.g., Peters 1983, Kramer and Bryant 1995a, b, Wootton 1998, Froese and Pauly 2000), as well as pinpointing the ecological role of a species in the aquatic food webs (e.g., Karpouzi and Stergiou 2003, Froese and Pauly 2008).

Gut length, in particular, provides important information on species' feeding habits in almost all vertebrate classes, e.g., fishes (Kramer and Bryant 1995a); reptiles (O’Grady et al. 2005); birds (e.g., Ricklefs 1996); and mammals (e.g., Chivers and Hladik 1980). In fishes, it can also be used as a reference point for interspecific comparisons (e.g., Al-Hussaini 1947). In this work, information on intestinal indices and relations between GL and body length and weight were compiled from the available bibliography. This data was related to species' feeding habits, fractional trophic level values (TROPHs) and taxonomy, as provided in FishBase (Froese and Pauly 2008), in order to identify possible patterns and correlations of feeding habits and evolutionary traits with intestinal growth.

\footnotetext{
${ }^{*}$ Correspondence: Dr. Paraskevi K. Karachle, Aristotle University, School of Biology, Department of Zoology, Laboratory of Ichthyology, Box 134, GR-541 24, Thessaloniki, Greece, phone: +30 2310 998356, fax: +30 2310 998279, e-mail: pkarachl@bio.auth.gr.

** The term "body length" we use denotes different types of length used by different authors.
} 


\section{MATERIALS AND METHODS}

An extended bibliographic search was conducted, in order to extract information related to gut of fishes. This search was based on online literature databases (e.g., Google Scholar, Scopus, Web of Science), covering a wide range of feeding-related papers (peer-reviewed and "grey" literature articles). The search was done using keywords, such as "gut", "intestine", "length", "morphology", "relative gut length", "Zihler's index", in various combinations, excluding all papers in relation to "nutrition and aquaculture", using analogous keywords. This was done consecutively several times, until no new results were found.

All available information provided in the original studies was tabulated by species, study area and year, and the following information was compiled: (a) length type and range of specimens studied, and number of individuals; (b) mean GL, relative GL (RGL), gut mass and relative gut mass, Zihler's index (ILW; Zihler 1982) and mean intestinal valve content; and (c) equations relating GL to either body length $(L)$ and/or weight $(W)$. Valid species name and taxonomy, fractional trophic level values (TROPHs) and habitat type (i.e., marine or freshwater species) were extracted from FishBase (Froese and Pauly 2008).

Mean RGL and ILW values RGL $_{m}$ and $\mathrm{ILW}_{m}$, respectively), as provided by the original author, were checked for normality (both were not normally distributed, since the values of skewness and kurtosis were outside the -2 to +2 range; Zar 1999) and grouped using the functional trophic groups, identified for the Mediterranean based on 332 stocks of 146 species by Stergiou and Karpouzi (2002).

Those are: (a) pure herbivores $(2.0<\mathrm{TROPH}<2.1)$; (b) omnivores with preference for plants $(2.1<\mathrm{TROPH}<2.9)$; (c) omnivores with preference for animals $(2.9<\mathrm{TROPH}$ $<3.7$ ); (d) carnivores with preference for decapods/fish $(3.7<\mathrm{TROPH}<4.0)$; and (e) carnivores with preference for fish/cephalopods $(4.0<\mathrm{TROPH}<4.5)$. The median $\mathrm{RGL}_{m}$ and $\mathrm{ILW}_{m}$ values of the functional groups were compared using the Kruskal-Wallis test (Zar 1999). Mean, minimum and maximum RGL and ILW, originally reported in the bibliography, were related to TROPH values.

Finally, based on the GL-body length $(L)$ relations, as given by the original authors, the regression lines were reconstructed. All regressions were plotted together and patterns of GL changes with $L$, according to species' feeding habits and taxonomy at the order level (only when $n>5$ families per order), were explored.

\section{RESULTS}

Overall, 766 data sets were collected from the literature, having information on fish gut (Table 1; Table A, electronic supplement, available at http://www.fishbase.org/ /Download/index.htm), which corresponded to 498 fish species belonging to 129 families and 29 orders. The most species rich family was Cichlidae (73 species; 14.7\%), followed by Cyprinidae (34 species; 6.8\%) and Gobiidae (25 species; 5\%), with the majority of the species (238 species; 47.8\%) belonging to the order Perciformes. Out of 498 species presented here, main habitat of 220 were freshwater, 233 marine and 37 both marine and freshwater (Table A).

Table 1

Information gathered from the related bibliography on fish gut

\begin{tabular}{|c|c|c|c|c|c|c|c|}
\hline Information & General & GL & RGL & GM & RGM & ILW & $\mathrm{mGVC}$ \\
\hline Number of cases & 766 & 287 & 454 & 1 & 13 & 170 & 3 \\
\hline Number of species & 498 & 118 & 293 & 1 & 5 & 123 & 3 \\
\hline Number of GL- $L$ relations & 79 & & & & & & \\
\hline linear $(Y=a+b X)$ & 9 & & & & & & \\
\hline exponential $\left(Y=a e^{b X}\right)$ & 10 & & & & & & \\
\hline power $\left(Y=a X^{b}\right)$ & 23 & & & & & & \\
\hline power $(\log Y=a+b \log X)$ & 37 & & & & & & \\
\hline freshwater species & 56 & & & & & & \\
\hline marine species & 23 & & & & & & \\
\hline Number of GL-weight relations & 22 & & & & & & \\
\hline power $(\log Y=a+b \log X)$ & 21 & & & & & & \\
\hline $\operatorname{logarithmic}(Y=a+b \ln X)$ & 1 & & & & & & \\
\hline freshwater species & 22 & & & & & & \\
\hline marine species & - & & & & & & \\
\hline Total number of sources & 59 & 17 & 38 & 1 & 2 & 7 & 1 \\
\hline peer-reviewed papers & 57 & 15 & 37 & 1 & 2 & 7 & 1 \\
\hline symposium proceedings & 1 & 1 & 1 & - & - & - & - \\
\hline $\mathrm{PhD}$ theses & 1 & 1 & - & - & - & - & - \\
\hline
\end{tabular}

$\overline{\mathrm{GL}}=$ gut length; $L=$ body length; $\mathrm{RGL}=$ relative GL; $\mathrm{GM}=$ gut mass; RGM = relative GM; ILW = Zihler's index (Zihler 1982); $\mathrm{mGVC}=$ mean intestinal valve content. 
The majority of the datasets referred to the Rio Charges system, Panama (120 datasets; Kramer and Bryant 1995a, b) and to a lesser extent to North Sea (83 datasets), the Mediterranean (58 datasets) and Red Sea (Ghardaqa; 56 datasets; Al-Hussaini 1947) (Table A). Sample size was reported in 642 data sets and ranged from 1 (58 cases) to 1461 (in the case of Heterotis niloticus), and for most data sets it was restricted to a small number of individuals (in $534(83.2 \%)$ cases: $n<50$ ). Information on length structure of the specimens studied was provided in 512 datasets $(66.8 \%)$, whereas the length range was provided in 364 datasets (Table A).

The type of length used in the majority of cases (448) was standard length, followed by total (178 cases) and fork length (66 cases) (Table A). The maximum reported body size of the 498 species ranged from $1.2 \mathrm{~cm}$, for Acanthopagrus berda and Ancistrus spinosus, to $73.0 \mathrm{~cm}$, for Chirocentrus dorab.

RGL values were reported in 454 cases (range $=$ 0.21-28.71; mean $\pm \mathrm{SE}=2.05 \pm 0.12$; median $=1.22$ ), and ILW values in 170 cases (range $=0.505-94.41$; mean $\pm \mathrm{SE}=5.96 \pm 0.65$; median $=3.85$ ) (Table A). For the mean values of both indices, there was an important overlap between the different functional trophic groups (Table 2, Fig. 1). Yet, Kruskal-Wallis test showed that the median $\mathrm{RGL}_{m}$ and $\mathrm{ILW}_{m}$ values differed significantly between groups ( $H$ : 70.01 and 18.71 respectively; $P<0.01$ in both cases; Fig. 1). Finally, mean, minimum and maximum RLG were negatively related with TROPH (Fig. 2). Significant regressions were also found between ILW and TROPH, but the $R^{2}$ values $\left(0.14<R^{2}<0.19, P<0.01\right)$ were lower than those of the RGL-TROPH regressions.

Out of 498 species, GL- $L$ relations were provided by the original author only for 79 cases ( 71 species, 48 freshwater and 23 marine species) (Table 1, Table A). All those equations were significant $(P<0.05)$. In 60 cases, the type of the relation was power (37 cases: $\log Y=a+b \log X ; 23$ cases: $\left.Y=a X^{b}\right)$, in 10 cases exponential $\left(Y=a e^{b X}\right)$ and in 9 cases linear $(Y=a+b X)$ (Table 1, Table A). GL- $W$ relations were provided only for 22 freshwater species. They were of the power type $(\log Y=a+b \log X)$ in 21 cases and logarith$\operatorname{mic}(Y=a+b \ln X)$ in only one case (Table 1, Table A).

Reconstruction of the GL $-L$ relation was possible for 67 out of the 71 species. Since the equations for the remaining four species (all significant; $P<0.05$ ) when solved have resulted to negative GL values, they were excluded from the analyses. When all these regressions were plotted together, there was a clear formation of two major groups based on the functional trophic groups (Fig. 3). The first one included all herbivores and omnivores with preference to plant material, along with two omnivores with preference to animal material (namely: Pomacanthus zonipectus, and Trichomycterus striatus ("Trichomycterus striatum")), and Ancistrus spinosus, for which no data on feeding habits is available. The second group included all the remaining omnivores with preference to animal material, and carnivores with preference to decapods, cephalopods and fish, as well as the remaining 20 species that were not classified into a functional trophic group (no TROPH value is provided in FishBase).

Finally, there was no group formation when the regressions were plotted all together and based on taxonomy at the order level (Fig. 4).

\section{DISCUSSION}

Bibliographic research revealed that the information related to the morphometrics of fish intestine is restricted to only a small number of species. Yet, this number could not be considered as low, taken into account that relations between length and weight, the most well studied parameters of the biology of fish (e.g., Anderson and Gutreuter 1983), are given for approximately over 2000 species (Binohlan and Pauly 2000). All the information presented here was either given in a few gut-related papers (such as those of e.g., Al-Hussaini 1947, Zihler 1982, Kramer and Bryant 1995a, b) and publications on fish morphology (e.g., Montgomery and Sunders 1985, Kassam et al. 2002) or usually provided as a by-product of research on feeding habits (e.g., Beumer 1978, Rosecchi 1983, Pölzer and Patzner 2000).

It is generally accepted that RGL $<1$ indicates carnivorous diet, $1<\mathrm{RGL}<3$ indicates omnivory, whereas values of RGL $>3$ indicate diet based on plant material or detritus (e.g., Ward-Campbell et al. 2005). Al-Hussaini (1947) identified four different trophic categories based on RGL for Red Sea fish species. Likewise, Kramer and Bryant (1995b) presented corresponding classifications, according to fish size (i.e., small, medium and large sized fishes). In the present study, the ranges of different $\mathrm{RGL}_{m}$ and $\mathrm{ILW}_{m}$ values per functional trophic group did not coincide with previously reported ones and there was no clear distinction of those ranges amongst the different trophic groups. Cleveland and Montgomery (2003) suggested that values of these indices, for species of specific feeding habits, that fall outside a predefined range, should be attributed to "unusual biological phenomena" (e.g., a herbivore preying on diatoms, which are easier to digest and provide larger amounts of energy due to storage of lipids rather than starch; Cleveland and Montgomery 2003). Therefore, such indices can provide a rough estimate on a species' feeding habits. However, they should be used with caution when comparisons among species with different or particular diets are being made (e.g., Cleveland and Montgomery 2003, German and Horn 2006).

When comparisons of such indices between species with different diets are attempted, evolutionary history (i.e., the influence of phylogeny) should be taken into consideration (e.g., Elliott and Bellwood 2003, German and Horn 2006). However this was not feasible in the present study.

The reconstructed regressions of the GL $-L$ relations when plotted in the same graph (Fig. 3), revealed that, for the same body length, species that include plant material in their diet, either exclusively (pure herbivores) or in significant proportions (omnivores with preference to plant material) have larger GL than fishes that prey on other 
animals (i.e., omnivores with preference to animal material, and carnivores). Only two species of the latter category were placed in the same group with plant-eating fish. For both of these species, TROPH values reported in FishBase are based on qualitative data and there are no quantitative descriptions on their feeding habits. The first one, Pomacanthus zonipectus, is a reef-associated species that preys mainly on algae, sponges and cnidarians (Pérez-España and Abitia-Cárdenas 1995, Froese and
Pauly 2008: Ref. No. 28023). Despite this species feeds with food of low TROPH (i.e., algae: TROPH $=1 \pm 0.00$; sponges: TROPH $=2 \pm 0.00$; Pauly et al. 2000b), the fact that cnidarians are also consumed $(\mathrm{TROPH}=2.50 \pm 0.52$; Pauly et al. 2000b) increases its TROPH. Hence, it is classified as an omnivore with preference to animal material $(\mathrm{TROPH}=3.1 \pm 0.32$; Froese and Pauly 2008). Taken into consideration the fact that fishes that prey upon items difficult to digest (e.g., plant material, crustacean exoskeletons,
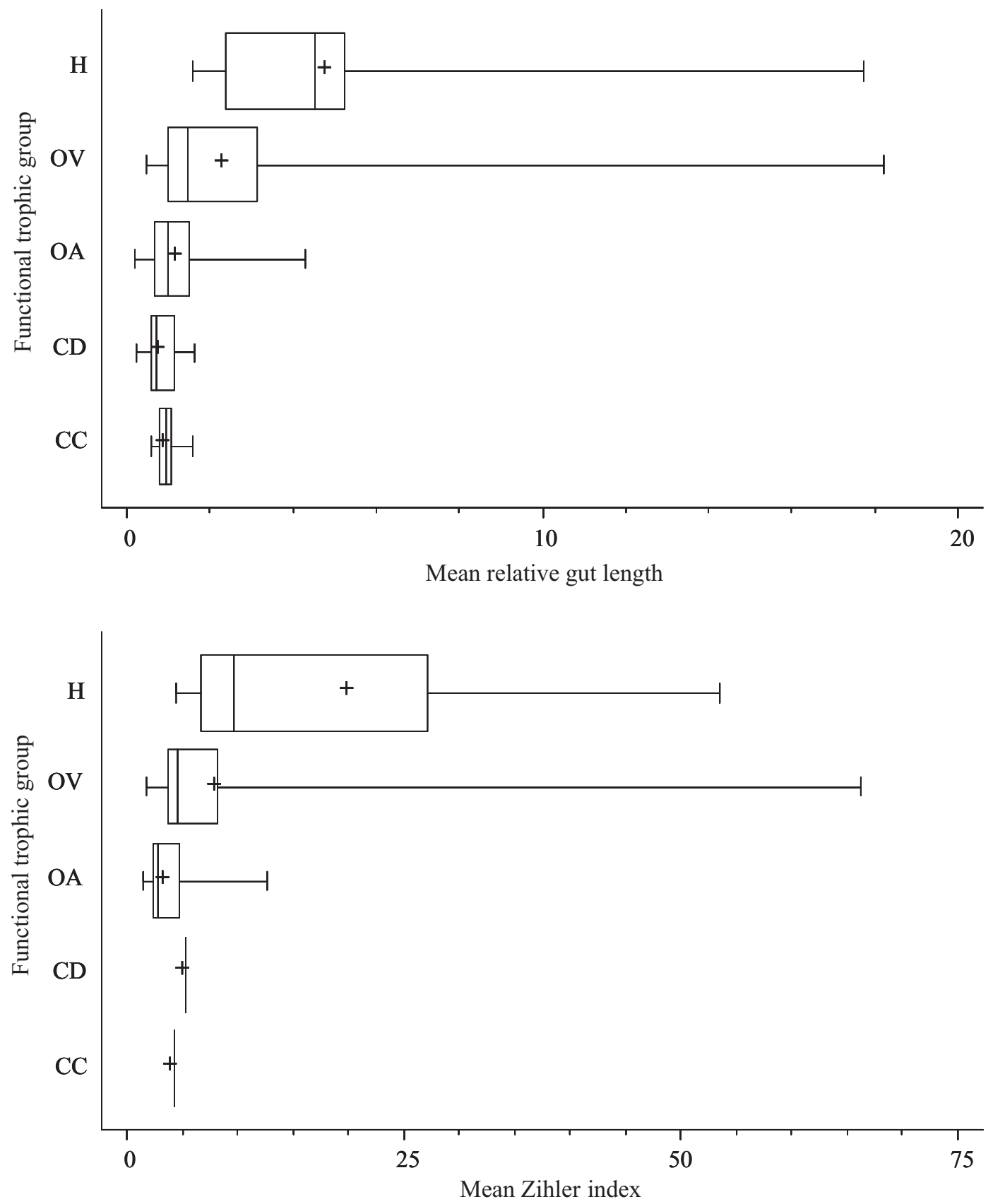

Fig. 1. Box-plots of mean relative gut length $\left(\mathrm{RGL}_{m}\right)$ and Zihler's index (ILW $\mathrm{IL}_{m}$ Z Zihler 1982) values provided by the original authors for the different functional trophic groups (FTGs) as identified by Stergiou and Karpouzi (2002); $\mathrm{H}=$ herbivores; $\mathrm{OA}=$ omnivores with preference to animal material; $\mathrm{CD}=$ carnivores with preference to decapods and fish; $\mathrm{CC}=$ carnivores with preference to fish and cephalopods; The central box indicates the range of values representing the $50 \%$ of cases around the median (vertical lines), the whiskers (horizontal lines) show the range of the values, and cross $(+)$ indicates the mean value 
Range and mean values of mean relative gut length $\left(\mathrm{RGL}_{m}\right)$ and Zihler's

Table 2 index (ILW $m$; Zihler 1982) values, provided by the original authors, and their corresponding standard error (SE), per functional trophic group (FTG; Stergiou and Karpouzi 2002)

\begin{tabular}{|c|c|c|c|c|c|c|}
\hline \multirow{2}{*}{ FTG } & \multicolumn{3}{|c|}{$\mathrm{RGL}_{m}$} & \multicolumn{3}{|c|}{ ILW $_{m}$} \\
\hline & $n$ & range & mean $\pm \mathrm{SE}$ & $n$ & range & mean $\pm \mathrm{SE}$ \\
\hline $\mathrm{H}$ & 30 & $1.6-17.75$ & $4.84 \pm 0.60$ & 5 & $4.49-53.6$ & $20.31 \pm 9.23$ \\
\hline $\mathrm{OV}$ & 78 & $0.47-18.2$ & $2.39 \pm 0.28$ & 42 & $1.7-66.22$ & $8.13 \pm 1.72$ \\
\hline $\mathrm{OA}$ & 217 & $0.21-4.3$ & $1.28 \pm 0.06$ & 26 & $1.5-12.7$ & $3.75 \pm 0.50$ \\
\hline $\mathrm{CD}$ & 9 & $0.24-1.64$ & $0.87 \pm 0.14$ & 1 & & 5.3 \\
\hline $\mathrm{CC}$ & 13 & $0.6-1.6$ & $0.98 \pm 0.07$ & 1 & & 4.3 \\
\hline
\end{tabular}

$\mathrm{H}=$ herbivores; $\mathrm{OA}=$ omnivores with preference to animal material; $\mathrm{CD}=$ carnivores with preference to decapods and fish; $\mathrm{CC}=$ carnivores with preference to fish and cephalopods; $n=$ number of cases.
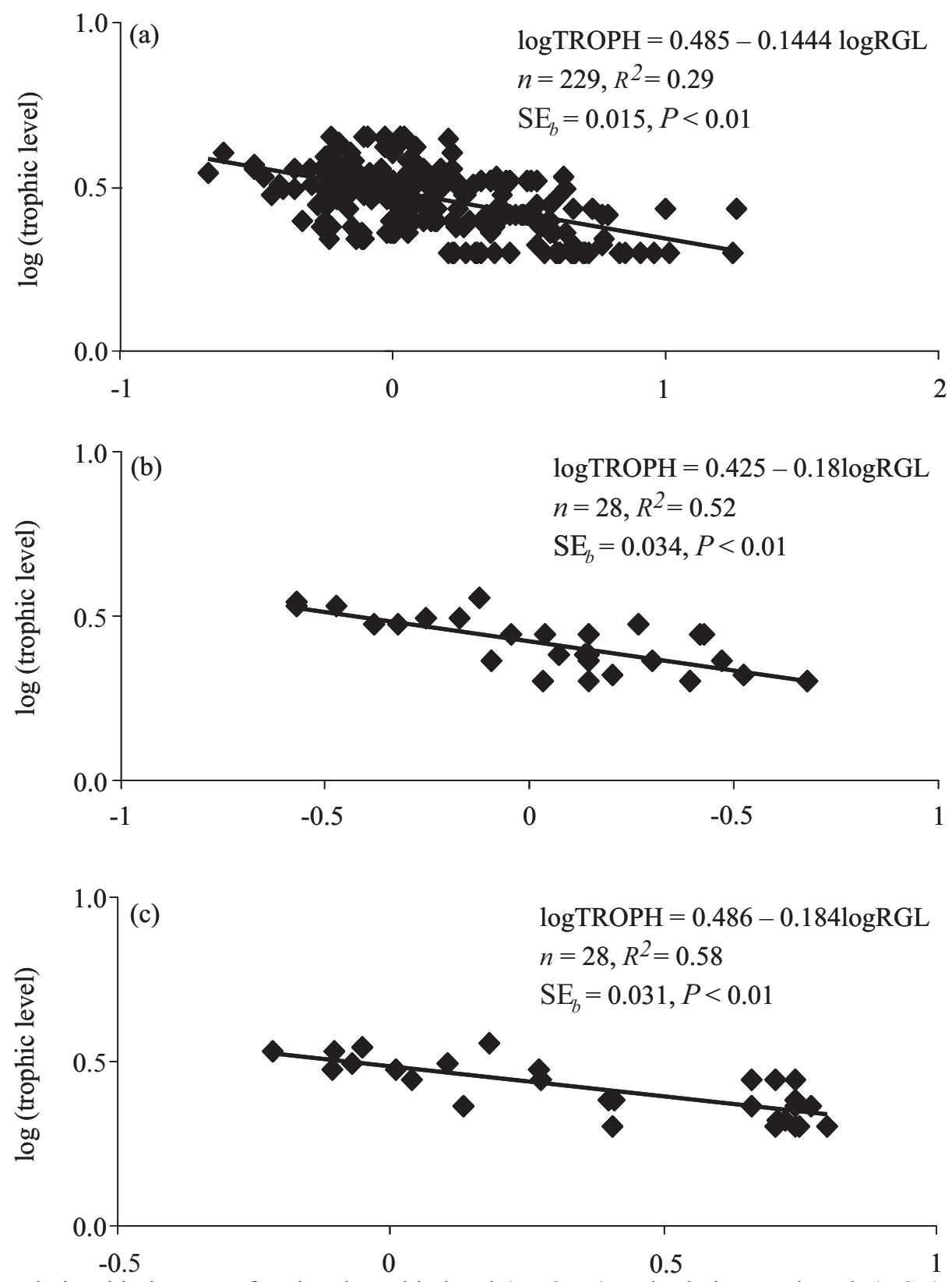

Fig. 2. Relationship between fractional trophic level (TROPH) and relative gut length (RGL) mean values (a), minimum values (b) and maximum values (c), as provided by the original author. $n=$ number of cases; $R^{2}=$ coefficient of determination; $\mathrm{SE}_{b}=$ standard error of slope 


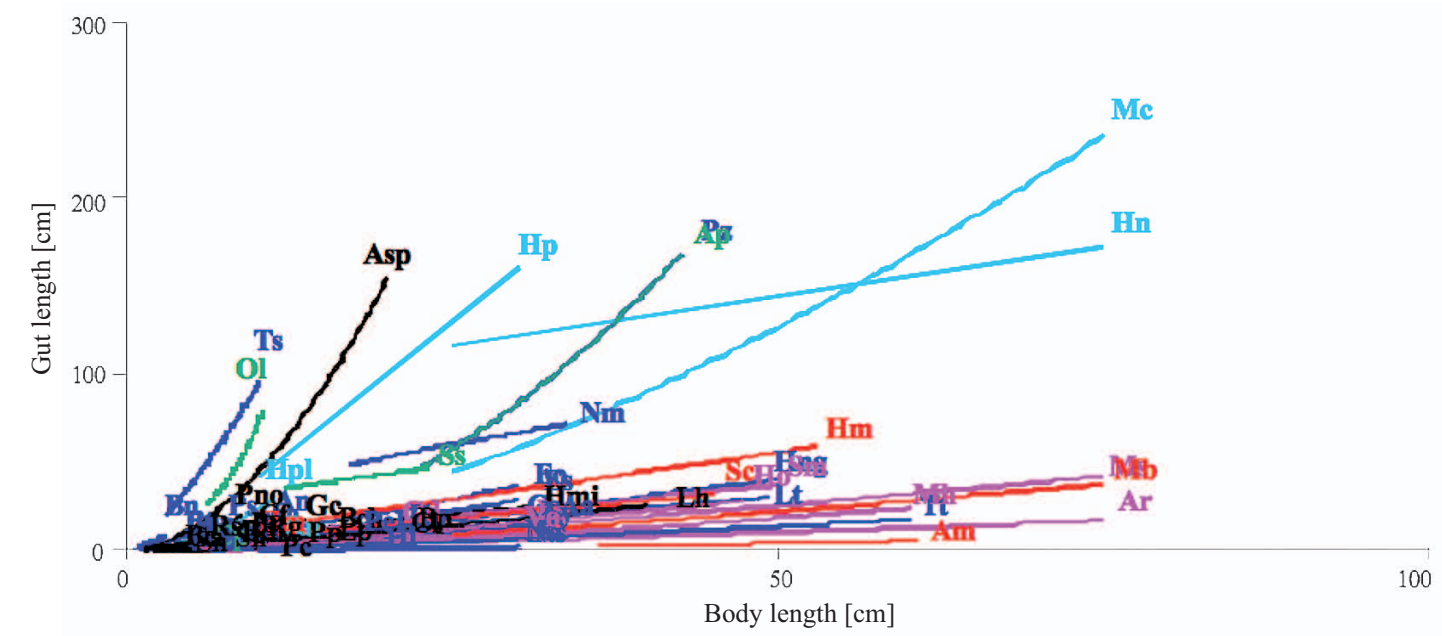

Fig. 3. Regressions between body length $(L$, in $\mathrm{cm})$ and gut length $(\mathrm{GL}$, in $\mathrm{cm})$ for 67 fish species; Equations are given in Table A, electronic supplement (available at http://www.fishbase.org/Download/index.htm); Different line colours correspond to different functional trophic groups (by Stergiou and Karpouzi 2002); green: herbivores; turquoise: omnivores with preference to vegetable material (OV); blue: omnivores with preference to animal material (OA); pink: carnivores with preference to decapods and fish $(\mathrm{CD})$; red: carnivores with preference to fish and cephalopods (CC); black: species that could not be classified to a functional trophic group because no trophic level values were reported in FishBase (www.fishbase.org; Froese and Pauly 2008); Ac = Aequidens coeruleopunctatus; Asp = Ancistrus spinosus; $\mathrm{Ar}=$ Anguilla rostrata $; \mathrm{An}=$ Annamia normani $; \mathrm{As}=$ Aphredoderus sayanus $; \mathrm{Ap}=$ Aplodactylus punctatus; $\mathrm{Aa}=$ Pennahia argentata ("Argyrosomus argentatus"); $\mathrm{Am}=$ Conger myriaster ("Astroconger myriaster"); $\mathrm{Bn}=$ Barbus neumayeri; $\mathrm{Bc}=$ Brachyrhaphis cascajalensis ("Brachyraphis cascajalensis"); $\mathrm{Bch}=$ Brycon chagrensis; $\mathrm{Bp}=$ Brycon petrosus; $\mathrm{Be}=$ Bryconamericus emperador; $\mathrm{Cf}=$ Chaetostoma fischeri; $\mathrm{Cl}=$ ("Channa limbata"); $\mathrm{Cp}=$ Cryptoheros panamensis ("Cichlasoma panamense"); Cc = Coelorinchus caelorhincus ("Coelorhynchus coelorhynchus"); Eo = Erimyzon oblongus; $\mathrm{Es}=$ Erimyzon sucetta; $\mathrm{Ea}=$ Esox americanus; $\mathrm{Gc}=$ Geophagus crassilabris; $\mathrm{Ga}=$ Gephyrocharax atricaudatus ("Gephyrocharax atricaudata"); Gd = Gobiomorus dormitor; $\mathrm{Hn}=$ Heterotis niloticus; Ho = Hexagramos otakii; Hp = Holacanthus passer; $\mathrm{Hm}=$ Hoplias malabaricus; $\mathrm{Hmi}=$ Hoplias microlepis; $\mathrm{Hi}=$ Hymenocephalus italicus; $\mathrm{Hng}=$ Hypentelium nigricans; $\mathrm{Hpn}=$ Hyphessobrycon panamensis; $\mathrm{Hpl}=$ Hypostomus plecostomus; $\mathrm{In}=$ Ameiurus natalis ("Ictalurus natalis"); $\mathrm{La}=$ Lepomis auritus; $\mathrm{Lp}=$ Lepomis punctatus; $\mathrm{Lh}=$ Pseudopleuronectes herzensteini ("Limanda herzensteini”); Ly = Pseudopleuronectes yokohamae ("Limanda yokohamae"); Lt; Liparis tanakai; $\mathrm{Mb}=$ Macrourus berglax; Mh = Macrourus holotrachys; $\mathrm{Ms}=$ Micropterus salmoides $; \mathrm{Mc}=$ Mugil cephalus $; \mathrm{Na}=$ Nezumia aequalis $; \mathrm{Ns}=$ Nezumia sclerorhynchus $; \mathrm{Nm}=$ Nibea mitsukurii $; \mathrm{Ol}=$ Osteochilus lini $; \mathrm{Pe}=$ Pagellus erythrinus $; \mathrm{Pn}=$ Percina nigrofasciata $; \mathrm{Pp}=$ Piabucina panamensis $; \mathrm{Pc}=$ Pimelodella chagresi $; \mathrm{Ps}=$ Poecilia sphenops $; \mathrm{Pz}=$ Pomacanthus zonipectus $;$ Pno $=$ Poropuntius normani; $\mathrm{Pr}=$ Puntius rhombeus; $\mathrm{Rp}=$ Rasbora paviana ("Rasbora paviei"); $\mathrm{Rw}=$ Rhamdia quelen ("Rhamdia wagneri"); $\mathrm{Rsp}$ $=$ Rhinogobius $\mathrm{sp} ; \mathrm{Ru}=$ Rineloricaria uracantha $; \mathrm{Rg}=$ Roeboides guatemalensis; $\mathrm{Ss}=$ Sarpa salpa $; \mathrm{Sn}=$ Schistura namboensis; $\mathrm{Tt}=$ Trachyrincus scabrus ("Trachyrhynchus trachyrhynchus"); Ts = Trichomycterus striatus ("Trichomycterus striatum"); $\mathrm{Vo}=$ Malacocephalus occidentalis ("Ventrifossa occidentalis"); and Xc = Xenentodon cancila

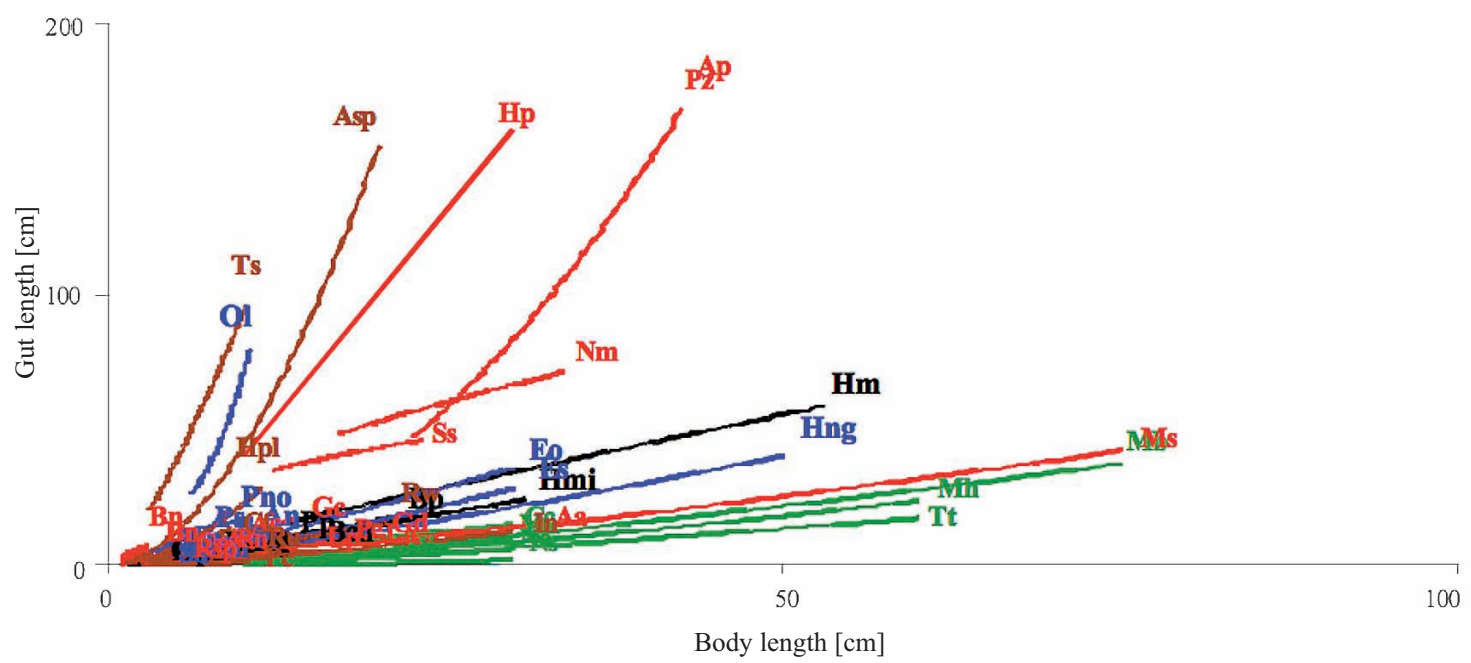

Fig. 4. Regressions between body length $(L$, in $\mathrm{cm})$ and gut length $(\mathrm{GL}$, in $\mathrm{cm})$ for 53 fish species; Equations are given in Table A, electronic supplement; different colours correspond to classification, based on species' order (by www.fishbase.org; Froese and Pauly 2008); black: Characiformes; blue: Cypriniformes; green: Gadiformes; red: Perciformes; and brown: Siluriformes (for species' abbreviations, see Fig. 3) 
sponge sclerites) tend to have longer intestines compared to their body length (e.g., Wootton 1998), it is not a surprise that this species groups with plant-eaters.

The second one, Trichomycterus striatus ("Trichomycterus striatum"), is a freshwater benthopelagic omnivore (TROPH = $3.2 \pm 0.40$; Froese and Pauly 2008), that feeds on insects (Froese and Pauly 2008: Ref. No. 6868) and other benthic invertebrates (Kramer and Bryant 1995a, b). The fact that this species grouped along with the plant-feeders, could be attributed to its body form, which, in general, seems to define the general form and structure of gut (e.g., Montgomery 1977, Verigina 1991, Cleveland and Montgomery 2003, Karachle 2008). Its elongated body, therefore, might allow the species to have a gut longer than its body, assuming that it possesses folds and loops.

Finally, the results of the regressions of mean, minimum and maximum RGL and ILW with TROPH (Fig. 2), and the reconstructed GL- $L$ relations (Fig. 3) reinforce the pattern that is believed to apply in all vertebrate classes, that is, herbivores tend to posses longer intestines than omnivores, and omnivores longer than carnivores.

Fish dissection is a prerequisite for the accumulation on raw data on fish intestine morphometrics, as well as stomach content analysis. Conversely, study of fish feeding habits can be performed without killing the specimens examined, using methods such as gastroscopy, stomach flushing, emetics (e.g., Kamler and Pope 2001). Yet, stomach content analysis for the estimation of a species' TROPH is a rather time-consuming and difficult procedure, compared to measuring gut length. For example, uncoiling and measuring gut length could be done in less than a minute. Conversely, stomach content analysis requires stomach dissection, extraction of the content, identification and shorting of the different food items, and finally counting and/or weighing of each food item separately. It is obvious that stomach analysis procedures demand from a few minutes (e.g., when food items are few and only weighed) up to more than an hour (e.g., if counting is required in cases such as in zoo- or phytoplanktivorous species).

Therefore, the indices presented here (RGL and ILW), which are relatively easy to calculate, can be used for a rough estimation of TROPH (i.e., using equations such as those given in Fig. 2). This is of great importance, especially for less studied species lacking feeding data and TROPH values, or in cases where only a few museum specimens are available, or in fossil fishes. Such estimations can be very useful for ecosystem management, as in the case of the Marine Trophic Index (Pauly and Watson 2005), which demands species- and location-specific TROPH estimates that are not always available (e.g., Karachle and Stergiou 2008), and for developing ecosystem models (e.g., Ecopath with Ecosim; Pauly et al. 2000a).

\section{ACKNOWLEDGEMENTS}

The authors would like to thank Dr R. Froese for his valuable comments and suggestions on the manuscript.

\section{REFERENCES}

Adite A., Winemiller K.O., Fiogbe E.D. 2005. Ontogenetic, seasonal, and spatial variation in the diet of Heterotis niloticus (Osteoglossiformes: Osteoglossidae) in the Sô River and Lake Hlan, Benin, West Africa. Environmental Biology of Fishes 73 (4): 367-378. [Cited in Table $A^{*}$.]

DOI: $10.1007 / \mathrm{s} 10641-004-5563-9$.

Ajayi T.O. 1982. Food and feeding habits of Raja species (Batoidei) in Carmarthen Bay, Bristol Channel. Journal of Marine Biological Association of the United Kingdom 62 (1): 215-223. [Cited in Table $\mathrm{A}^{*}$.] DOI: $10.1017 / \mathrm{S} 0025315400020233$.

Al-Hussaini A.H. 1947. The feeding habits and the morphology of the alimentary tract of some teleosts living in the neighbourhood of the Marine Biological Station, Ghardaqa, Red Sea. Publications of the Marine Biological Station, Ghardaqa (Red Sea) 5: 1-61.

Al-Hussaini A.H. 1949. On the functional morphology of the alimentary tract of some fish in relation to differences in their feeding habits: anatomy and histology. Quarterly Journal of Microscopical Science 90 (2): 109-139. [Cited in Table A*.]

Anatolić B., Skaramuca B., Špan A., Mušin D., Sanko-Njire J. 1994. Food and feeding habits of a herbivore fish Sarpa salpa (L.) (Teleostei, Sparidae) in the southern Adriatic (Croatia). Acta Adriatica 35 (1/2): 45-52. [Cited in Table A*.]

Anderson R.O., Gutreuter S.J. 1983. Length, weight, and associated structural indices. Pp. 283-300. In: Nielsen L.A., Johnson D.L. (eds) Fisheries techniques. American Fisheries Society, Bethesda, MD, USA.

Benavides A.G., Cancino J.M., Ojeda F.P. 1994. Ontogenetic changes in gut dimensions and macroalgal digestibility in the marine herbivorous fish, Aplodactylus punctatus. Functional Ecology 8: 46-51. [Cited in Table A*.]

Beumer J.P. 1978. Feeding ecology of four fishes from a mangrove creek in north Queensland, Australia. Journal of Fish Biology 12 (5): 475-490.

DOI: $10.1111 / \mathrm{j} .1095-8649.1978 . t b 04191 . x$.

Binohlan C., Pauly D. 2000. The length-weight table. Pp. 121-123. In: Froese R., Pauly D. (eds.) FishBase 2000: concepts, design and data sources. ICLARM, Manila.

Blay J.jr. 1995. Food and feeding habits of four species of juvenile mullet (Mugilidae) in a tidal lagoon in Ghana. Journal of Fish Biology 46 (1): 134-141. [Cited in Table A*.] DOI: 10.1111/j.1095-8649.1995.tb05952.x.

Braber L., de Groot S.J. 1973. On the morphology of the alimentary tract of flatfishes (Pleuronectiformes). Journal of Fish Biology 5 (2): 147-153. [Cited in Table A*.] DOI: $10.1111 / j .1095-8649.1973 . t b 04443 . x$.

Bradai M.N., Bouain A. 1990. Regime alimentaire de Scorpaena porcus et de S. scrofa (Teleostei, Scorpaenidae) du golfe du Gabes, Tunisie. Cybium 14 (3): 207-216. [Cited in Table $\mathrm{A}^{*}$.]

Cailliet G.M., Ebeling A.W. 1990. The vertical distribution and feeding habits of two common midwater fishes (Leuroglossus stilbius and Stenobrachius leucopsarus) off Santa Barbara. Reports - California Cooperative Oceanic Fisheries Investigations 31: 106-123. 
Carrassón M., Matallanas J. 1994. Morphometric characteristics of the alimentary tract of deep-sea Mediterranean teleosts in relation to their feeding habits. Marine Biology 118 (2): 319-322. [Cited in Table A*.]

DOI: $10.1007 / \mathrm{BF} 00349799$.

Chivers D.J., Hladik C.M. 1980. Morphology of the gastrointestinal tract in primates: comparisons with other mammals in relation to diet. Journal of Morphology 166 (3): 337-386. DOI: $10.1002 /$ jmor.1051660306.

Cleveland A., Montgomery Z.W.L. 2003. Gut characteristics and assimilation efficiencies in two species of herbivorous damselfishes (Pomacentridae: Stegastes dorsopunicans and S. planifrons). Marine Biology 142 (1): 35-44. DOI: 10.1007/s00227-002-0916-4.

Dankwa H.R., Blay J.jr., Yankson K. 2005. Food and feeding habits of grey mullets (Pisces: Mugilidae) in two estuaries in Ghana. West Africa Journal of Applied Ecology 8 (1): 65-77. [Cited in Table $A^{*}$.]

De Groot S.J. 1971. On the interrelationships between morphology of the alimentary tract, food and feeding behaviour in flatfishes (Pisces: Pleuronectiformes). Netherlands Journal of Sea Research 5 (2): 121-196. [Cited in Table A*.] DOI: 10.1016/0077-7579(71)90008-1.

Dejen E., Vijverberg J., De Graaf M., Sibbing F.A. 2006. Predicting and testing resource partitioning in a tropical fish assemblage of zooplanktivorous 'barbs': an ecomorphological approach. Journal of Fish Biology 69 (5): 1356-1378. DOI: 10.1111/j.1095-8649.2006.01197.x [Cited in Table A*.]

Drewe K.E., Horn M.H., Dickson K.A., Gawlicka A. 2004. Insectivore to frugivore: ontogenetic changes in gut morphology and digestive enzyme activity in the characid fish Brycon guatemalensis from Costa Rican rain forest streams. Journal of Fish Biology 64 (4): 890-902. [Cited in Table A*.] DOI: $10.1111 /$ j.1095-8649.2004.0357.x.

Dumay O., Tari P.S., Tomasini J.A., Mouillot D. 2004. Functional groups of lagoon fish species in Languedoc Roussillon, southern France. Journal of Fish Biology 64 (4): 970-983. [Cited in Table A*.] DOI: 10.1111/j.1095-8649.2004.00365.x.

Elliott J.P., Bellwood D.R. 2003. Alimentary tract morphology and diet in three coral reef fish families. Journal of Fish Biology 63 (6): 1598-1609.

DOI: $10.1111 /$ j.1095-8649.2003.00272.x.

Eggold B.T., Motta P.J. 1992. Ontogenetic dietary shifts and morphological correlates in striped mullet, Mugil cephalus. Environmental Biology of Fishes 34 (2): 139-158. [Cited in Table A*.] DOI: 10.1007/BF00002390.

Froese R., Pauly D. (eds.) 2000. FishBase 2000. Concepts, design and data sources. ICLARM, Manila.

Froese R., Pauly D. (eds.) 2008. FishBase. [version 07/2008] http://www.fishbase.org.

Geevarghese C. 1983. Morphology of the alimentary tract in relation to diet among gobioid fishes. Journal of Natural History 17 (5): 731-741. [Cited in Table A*.] DOI: $10.1080 / 00222938300770571$.

Geistdoerfer P. 1981. Morphologie et histologie de l'appareil digestif des Macrouridae (Teleosteens). II. Morphologie de l'appareil digestif. Cybium 5 (2): 3-44. [Cited in Table A*.]
German D.P., Horn M.H. 2006. Gut length and mass in herbivorous and carnivorous prickleback fishes (Teleostei: Stichaeidae): ontogenetic, dietary, and phylogenetic effects. Marine Biology 148 (5): 1123-1134.

DOI: $10.1007 / \mathrm{s} 00227-005-0149-4$.

Gomiero L.M., Manzatto A.G., Braga F.M.S. 2008. The role of riverine forests for food supply for the omnivorous fish Brycon opalinus Cuvier, 1819 (Characidae) in the Serra do Mar, Southeast Brazil. Brazilian Journal of Biology 68 (2): 321-328. [Cited in Table A*.] DOI: $10.1590 /$ S1519-69842008000200013.

Gunn J.S., Milward N.E. 1985. The food, feeding habits and feeding structures of the whiting species Sillago sihama (Forsskål) and Sillago analis Whitley from Townsville, North Queensland, Australia. Journal of Fish Biology 26 (4): 411-427. [Cited in Table A*.] DOI: 10.1111/j.1095-8649.1985.tb04281.x.

Hallacher L.E., Roberts D.A. 1985. Differential utilization of space and food by the inshore rockfishes (Scorpaenidae: Sebastes) of Carmel Bay, California. Environmental Biology of Fishes 12 (2): 91-110. [Cited in Table A*.] DOI: $10.1007 / B F 00002762$.

Hart P.J.B. 1997. Foraging tactics. Pp. 104-133. In: Godin J.G.J. (ed.) Behavioural ecology of teleost fishes. Oxford University Press, New York.

Havelange S., Lepoint G., Dauby P., Bouquegneau J.-M. 1997. Feeding of the sparid fish Sarpa salpa in a seagrass ecosystem: diet and carbon flux. Marine Ecology 18 (4): 289-297. [Cited in Table A*.] DOI: $10.1111 / j .1439-0485.1997 . t b 00443 . x$.

Herder F., Freyhof J. 2006. Resource partitioning in a tropical stream fish assemblage. Journal of Fish Biology 69: 571-589. DOI: $10.1111 / j .1095-8649.2006 .01126 . x$ [Cited in Table A*.]

Hofer R. 1988. Morphological adaptations of the digestive tract of tropical cyprinids and cichlids to diet. Journal of Fish Biology 33 (3): 399-408. [Cited in Table A*.] DOI: $10.1111 / \mathrm{j} .1095-8649.1988 . t b 05481 . x$.

Honda H. 1984. Food acquisition patterns in some demersal teleosts. Tohoku Journal of Agricultural Research 35 (1): 33-54. [Cited in Table A*.]

Horstkotte J., Strecker U. 2005. Trophic differentiation in the phylogenetically young Cyprinodon species flock (Cyprinodontidae, Teleostei) from Laguna Chichancanab (Mexico). Biological Journal of the Linnean Society 85 (1): 125-134. [Cited in Table $\mathrm{A}^{*}$.] DOI: 10.1111/j.1095-8312.2005.00476.x.

Hugueny B., Pouilly M. 1999. Morphological correlates of diet in an assemblage of West African freshwater fishes. Journal of Fish Biology 54 (6): 1310-1325. [Cited in Table $A^{*}$.] DOI: 10.1111/j.1095-8649.1999.tb02057.x.

Hussain N.A., Naama A.K. 1992. On the morphology of the alimentary tract of some fishes from Khor al-Zubair, Northwest Arabian Gulf, Iraq. Journal of Applied Ichthyology 8 (1-4): 240-245. [Cited in Table $A^{*}$.] DOI: $10.1111 / j .1439-0426.1992 . t b 00689 . x$.

Juanes F. 1994. What determines prey size selectivity in piscivorous fishes? Pp. 78-100. In: Stouder D.J., Fresh K.L., Feller R.J. (eds.) Theory and application in fish feeding ecol- 
ogy. Belle W. Baruch Library in Marine Sciences, No. 18, University of South Carolina Press, Columbia, SC, USA.

Juanes F., Conover D.O. 1994. Piscivory and prey size selection in young-of-the-year bluefish: predator preference or size-dependent capture success? Marine Ecology Progress Series 114: 59-69.

Junger H., Kotrschal K., Goldschmid A. 1989. Comparative morphology and ecomorphology of the gut in European cyprinids (Teleostei). Journal of Fish Biology 34 (2): 315-326. [Cited in Table A*.] DOI: $10.1111 / j .1095-8649.1989 . t b 03312 . x$.

Kaiser M.J., Hughes R.N. 1993. Factors affecting the behavioural mechanisms of diet selection in fishes. Marine Behaviour and Physiology 23 (1-4): 105-118.

Kamler J.F., Pope K.L. 2001. Nonlethal methods of examining fish stomach contents. Reviews in Fishery Science 9 (1): 1-11. DOI: 10.1080/20016491101663.

Karachle P.K. 2008. Oikologia tīs diatrofīs tōn sīmantikoterōn ichthyapothematōn tou Voreiou Aigaiou. [Feeding ecology of the most important fish stock in the North Aegean Sea.] $\mathrm{PhD}$ Dissertation, Aristotle University of Thessaloniki, Greece. [In Greek.]

Karachle P.K., Stergiou K.I. 2006. Relationship between gut length, feeding and trophic level for several fish species from the N-NW Aegean Sea (Greece). P. 228. In: Anonymous (ed.) Proceedings of the 8th Panhellenic Symposium of Oceanography and Fisheries. 4-8 June 2006, Thessaloniki, Greece.

Karachle P.K., Stergiou K.I., 2007. "Uncoiling" information on fish gut. Pp. 17-18. In: Snoeks J., Boden G., Musschoot T. (eds.) 5rd FishBase Mini Symposium. 5 September 2007, Tervuren, Belgium. Royal Museum for Central Africa (RMCA).

Karachle P.K., Stergiou K.I. 2008. The effect of season and sex on trophic levels of marine fishes. Journal of Fish Biology 72 (6): 1463-1487. DOI: $10.1111 /$ j.1095-8649.2008.01809.x.

Karpouzi V.S., Stergiou K.I. 2003. The relationships between mouth size and shape and body length for 18 species of marine fishes and their trophic implications. Journal of Fish Biology 62 (6): 1353-1365. DOI: 10.1046/j.1095-8649.2003.00118.x.

Kassam D.D., Sato T., Yamaoka K. 2002. Landmark-based morphometric analysis of the body shape of two sympatric species, Ctenopharynx pictus and Otopharynx sp. "heterodon nankhumba" (Teleostei: Cichlidae), from Lake Malawi. Ichthyological Research 49 (4): 340-345. DOI: $10.1007 /$ s102280200050.

Keast A., Webb D. 1966. Mouth and body form relative to feeding ecology in the fish fauna of a small lake, Lake Opinicon, Ontario. Journal of Fisheries Research Board of Canada 23 (12): 1845-1874.

Kramer D.L., Bryant M.J. 1995a. Intestine length in the fishes of a tropical stream: 1. Ontogenetic allometry. Environmental Biology of Fishes 42 (2): 115-127. DOI: 10.1007/BF00001990.

Kramer D.L., Bryant M.J. 1995b. Intestine length in the fishes of a tropical stream: 2. Relationships to diet - the long and short of a convoluted issue. Environmental Biology of Fishes 42 (2): 129-141. DOI: 10.1007/BF00001991.
Labropoulou M. 1995.Oikología diatrofîs venthikōn psariōn ston Kólpo tou Irrakleíou [Feeding ecology of the demersal fish species in Iraklion Bay.] PhD Dissertation, University of Crete, Iraklion, Greece. [In Greek.] [Cited in Table A*.]

Labropoulou M., Eleftheriou A. 1997. The foraging ecology of two pairs of congeneric demersal fish species: importance of morphological characteristics in prey selection. Journal of Fish Biology 50 (2): 324-340. [Cited in Table A*.] DOI: 10.1111/j.1095-8649.1997.tb01361.x.

Logothetis E.A., Horn M.H., Dickson K.A. 2001. Gut morphology and function in Atherinops affinis (Teleostei: Atherinopsidae), a stomachless omnivore feeding on macroalgae. Journal of Fish Biology 59 (5): 1298-1312. [Cited in Table A*.] DOI: 10.1006/jfbi.2001.1740.

Lückstädt C., Reiti T. 2000. Investigations on the feeding behavior of juvenile milkfish (Chanos chanos Forsskål) in brackishwater lagoons on South Tarawa, Kiribati. Verhandlungen der Gesellschaft fur Ichthyologie 3: 37-43. [Cited in Table $\mathrm{A}^{*}$.]

Montgomery W.L. 1977. Diet and gut morphology in fishes, with special reference to the monkeyface prickleback, Cebidichthys violaceus (Stichaeidae: Blennioidei). Copeia 1977 (1): 178-182. [Cited in Table $A^{*}$.]

Montgomery J.C., Saunders A.J. 1985. Functional morphology of the piper Hyporhamphus ihi with reference to the role of the lateral line in feeding. Proceedings of the Royal Society of London. Series B, Biological Sciences 224 (1235): 197-208. DOI: 10.1098/rspb.1985.0029.

Muñoz A.A., Ojeda F.P. 2000. Ontogenetic changes in the diet of the herbivorous Scartichthys viridis in a rocky intertidal zone in central Chile. Journal of Fish Biology 56 (4): 986-998. [Cited in Table A*.] DOI: $10.1006 /$ jfbi.1999.1224.

Murie D.J. 1994. Comparative allometric growth of the gastrointestinal tract of two sympatric congeners, copper rockfish (Sebastes caurinus) and quillback rockfish (S. maliger). Journal of Fish Biology 44 (4): 597-605. [Cited in Table A* ${ }^{*}$ ] DOI: 10.1111/j.1095-8649.1994.tb01236.x.

Nakagawa H., Umino T., Sekimoto T., Ambas I., Montgomery A.L., Nakano T. 2002. Characterization of the digestive tract of wild ayu. Fisheries Science 68 (2): 341-346. [Cited in Table A*.] DOI: 10.1046/j.1444-2906.2002.00431.x.

O'Grady S.P., Morando M., Avila L., Dearing M.D. 2005. Correlating diet and digestive tract specialization: Examples from the lizard family Liolaemidae. Zoology 108 (3): 201-210. DOI: 10.1016/j.zool.2005.06.002.

Ojeda F.P. 1986. Morphological characterization of the alimentary tract of Antarctic fishes and its relation to feeding habits. Polar Biology 5 (2): 125-128. [Cited in Table A*.]

Pauly D., Christensen V., Walters C. 2000a. Ecopath, Ecosim, and Ecospace as tools for evaluating ecosystem impact of fisheries. ICES Journal of Marine Science 57 (3): 697-706. DOI: $10.1006 / j m s c .2000 .0726$.

Pauly D., Froese R., Sa-a P., Palomares M.L., Christensen V., Rius J. 2000b. Trophlab manual. ICLARM, Manila, Philippines.

Pauly D., Watson R. 2005. Background and interpretation of the 'Marine Trophic Index' as a measure of biodiversity. 
Philosophical Transactions of Royal Society Series B 360: 415-423. DOI: 10.1098/rstb.2004.1597.

Pérez-España H., Abitia-Cárdenas L.A. 1996. Description of the digestive tract and feeding habits of the king angelfish and the Cortes angelfish. Journal of Fish Biology 48 (5): 807-817. DOI: 10.1111/j.1095-8649.1996.tb01477.x.

Peters R.H. 1983. The ecological implications of body size. Cambridge Studies in Ecology, Cambridge University Press, New York.

Pölzer W., Patzner R.A. 2000. Nahrungsspektrum und Gebi $\beta$ der Anemonengrundel Gobius bucchichi (Gobiidae) im Mettelmeer. Zeitschrift für Fischkunde 5 (2): 83-90.

Pouilly M., Lino F., Bretenoux J.-G., Rosales C. 2003. Dietary-morphological relationships in a fish assemblage of the Bolivian Amazonian floodplain. Journal of Fish Biology 62 (5): 1137-1158. [Cited in Table $A^{*}$.] DOI: 10.1046/j.1095-8649.2003.00108.x.

Ribble D.O., Smith M.H. 1983. Relative intestine length and feeding ecology of freshwater fishes. Growth 47 (3): 292-300. [Cited in Table A*.]

Ricklefs R.E. 1996. Morphometry of the digestive tracts of some passerine birds. Condor 98: 279-292.

Rosecchi E. 1983. Regime alimentaire du pageot, Pagellus erythrinus, Linne 1758, (Pisces, Sparidae) dans le Golfe du Lion. Cybium 7 (3): 17-29.

Schaack S., Chapman L.J. 2004. Interdemic variation in the foraging ecology of the African cyprinid, Barbus neumayeri. Environmental Biology of Fishes 70 (2): 95-105. [Cited in Table A*.] DOI: 10.1023/B:EBFI.0000029339.25250.87.

Schmitt R.J., Holbrook S.J. 1984. Gape-limitation, foraging tactics and prey size selectivity of two microcarnivorous species of fish. Oecologia 63 (1): 6-12. DOI: 10.1007/BF00379778.

Serajuddin M., Khan A.A., Mustafa S. 1998. Food and feeding habits of the spiny eel, Mastacembelus armatus. Asian Fisheries Science 11 (3-4): 271-278.

Stergiou K.I., Karpouzi V.S. 2002. Feeding habits and trophic levels of Mediterranean fish. Reviews in Fish Biology and Fisheries 11 (3): 217-254. DOI: 10.1023/A:1020556722822.

Stergiou K.I., Karpouzi V.S. 2003. Length-girth relationships for several marine fishes. Fisheries Research 60 (1): 161-168. DOI: 10.1016/S0165-7836(02)00077-2.
Stoner A.W., Livingston R.J. 1984. Ontogenetic patterns in diet and feeding morphology in sympatric sparid fishes from seagrass meadows. Copeia 1984 (1): 174-187. [Cited in Table A*.]

Teixeira de Mello F., Iglesias C., Borthagaray A.I., Mazzeo N., Vilches J., Larrea D., Ballabio R. 2006. Ontogenetic allometric coefficient changes: implications of diet shift and morphometric traits in Hoplias malbaricus (Bloch) (Characiforme, Erythrinidae). Journal of Fish Biology 69 (6): 1770-1778. [Cited in Table A*.] DOI: $10.1111 / \mathrm{j} .1095-8649.2006 .01245 . x$.

Verigina I.A. 1991. Basic adaptations of the digestive system in bony fishes as a function of diet. Journal of Ichthyology 31 (2): 8-20.

Ward-Campbell B.M.S., Beamish F.W.H. 2005. Ontogenetic changes in morphology and diet in the snakehead, Channa limbata, a predatory fish in western Thailand. Environmental Biology of Fishes 72 (3): 251-257. [Cited in Table A*.] DOI: $10.1007 / \mathrm{s} 10641-004-1744-9$.

Ward-Campbell B.M.S, Beamish F.W.H., Kongchaiya C. 2005. Morphological characteristics in relation to diet in five coexisting Thai fish species. Journal of Fish Biology 67 (5): 1266-1279. DOI: 10.1111/j.1095-8649.2005.00821.x.

Wootton R.J. 1998. Ecology of teleost fishes. 2nd edn. Fish and Fisheries Series No. 24, Kluwer Academic Publishers, London.

Zar J.H. 1999. Biostatistical analysis. 4th edn. Prentice Hall, Upper Saddle River, NJ, USA.

Zihler F. 1982. Gross morphology and configuration of digestive tracts of Cichlidae (Teleostei, Perciformes): phylogenetic and functional significance. Netherlands Journal of Zoology 32 (4): 544-571. DOI: 10.1163/002829682X00210.

Received: 24 March 2009

Accepted: 4 December 2009 Published electronically: 25 June 2010 